\title{
Research on Development Trends of China's Design Education Based on Chinese-Western Comparison
}

\author{
Huazheng Liu \\ Communication and animation Institute, Qingdao University of Science and Technology, No.99, \\ Songling Road, Laoshan District, Qingdao, Shandong Province , China
}

liuhuazheng1949@163.com

Keywords: Design education; Philosophies; Practice; Innovation; Comparison

\begin{abstract}
The paper spreads the discussion about the theme of the current status and differences of the Chinese and Western design education, summarizes the features and advantages of the Western design education, introduces the current situation of Western design education and its advanced design education philosophies and teaching modes, and points out that lifting philosophies, focus on innovation and emphasis on personality are the basic measures for the reform of China's current art design education through the comparison with the current status of China's design education.

"Education refers to all the processes of transmitting and learning the human's civilization achievements - all kinds of knowledge, skills and social life experience in general; the processes are social practical activities which can improve the inference and judgment abilities and promote individual socialization and society individualization and roughly make Intellectual preparation for a person to be faced with mature life." This is the basic interpretation of the concept of education. Design education is greatly different from common education, and the process of art design education is more complicated. With the social and economic development and advancement, China's design education is currently in a new period of fast reform and development, and it is positive for the advancement of China's design education to understand the history, development and current situation of Western design education, and learn from the advanced education philosophies of Western design.
\end{abstract}

\section{Philosophies - Reflection of the Nature and Connotation of Design Education}

What is a philosophy? Philosophy is equal to concept in meaning, a concept is a thinking mode of reflecting an object's essential attributes (Cihai), and is from general rules and reflect the object's nature and connotation in a brand-new thinking and expression form. In the western countries, contemporary art and design education don't have a uniform or clear teaching system, but the design colleges have their explicit education thoughts which convey absolutely clear education philosophies. For the western design educators, art individualization, discipline non-standardization and social demand practicality are more important than a uniform teaching system. The core thought of the western design education is the emphasis on creativity and individualization training and the self-value realization and identification. The education of western countries values the lifting of thinking concepts over the traditional art education model with pure skill training. Therefore, the art design education process is much more complex than the common knowledge education. For students, they should firstly learn to think and seek for self-improvement of skills in the thinking process as skills are auxiliary. The western design educators think that a man's career growth process is a long one, and only when he learns to correctly think, can he be able to cope with the challenges from constantly emerging new matters; the western colleges are open-ended and develop spontaneously with the society, their clear education philosophies and innovative thinking are rooted in every education level.

Compared with the western design education, China's design education has a uniform, integral and clear teaching system and emphasizes on the same standard, but lacks an integral and clear education philosophy for each level. China's design education and system is not generated by the driving of its art tradition, but based on the patterns of the colleges of Europe and the Former Soviet 
Union at the end of the 19th Century under the background of basically being independent from its art tradition. China's older art educators introduced the education pattern of the traditional western colleges in the 1920s, but China's art education lacked its own philosophies as it was independent from its art tradition. At present, the design industry has gradually become an important part of socioeconomic development, to adapt to the social advancement and high-speed economic development, China's art education reform has been started, especially in the field of design education, it is necessary to start from the integration and reshaping of education philosophies, lift the education thinking and concepts, and correctly lead the reform and development of design education.

\section{Open Teaching}

Using the United States in the western countries as the example, its colleges are the world's most open ones, the "openness" includes the openness of academic attitudes, that of thinking modes, and that of teaching and learning methods, and realizes the exclusiveness of education patterns in a real sense. Many western colleges order teachers not to use one and the same course design twice, and this urges teachers to constantly pay attention to and take in new information in teaching, and constantly update their teaching philosophies and contents. But the current design educators in China's design colleges take it for granted that they consider their academic value orientation as the standards of instruction, which is exactly the disadvantage of China' art design education; individualized teaching has been put forward by our ancestor for one or two hundred years, but isn't well carried out and implemented now. The western colleges go out of their way to import various existing off-campus academic states into their teaching, and form an academic atmosphere of letting a hundred schools of thought contend. The students in many academic colleges cannot stop discussing and communicating, the collision of thinking can always make a new thought from another one, and completely express it via vision and concepts.

But the Chinese students are accustomed to cramming teaching from childhood, they receive education in a passive posture, have weak initiative, they lack communication and exchange, not because they are lazy, but because they lack initiative thinking.

\section{Practice - the Soul of Design Education}

Any good creativity or idea should be realized through practice. In practice, students can understand and experience basic design programs and methods and cultivate the cooperative spirit. The training of practical ability is also the need for adapting to the society; the weak operational ability makes it impossible to implement many novel and applicable design. The practical ability is mainly from rich life experience and design practical experience, students can enter into the role as designer through practice, after all, students finally need to leave school and step into the society, the society is the best platform to test their knowledge and ability. In the western art colleges, the professional role education accompanies the students from the very first day till graduation, including success education, self-value and self-expression education, and other courses. A huge amount of teaching courses offered by many famous colleges are actually the practical cooperative projects with large companies, for example, Chinese and Western Art Design College in Los Angeles and the Major of Ship Design in College for Creative Studies (CCS) in Detroit cooperate with the globe's large auto manufacturers and product manufacturers. While making great contributions to the development of the global auto and auto product manufacturing industries, the cooperation also provides students with good internship opportunities. The students can closely combine the social demands through the practice courses and then step into their occupational pathways quickly. But the current students' design practices in China's design colleges are often limited to the assignments of related courses, the assignment topics are determined by teachers according to the classroom contents, and have certain gaps with the actual subject topics, and that the students are less exposed to the practical design projects cause the current status that they have weak operational ability. 
In the coming few years, China's education market will be gradually open to the western world, the western art education will promote China's local art education and make the latter diversified when it is introduced to China, but it is also a challenge for China's local art education, in front of the challenge, we must fundamentally reform China's art design education to cope with the new situation of China's art design education.

\section{Lift Philosophies}

A philosophy is a designer's spiritual reaction and the internal soul of his works, and can fundamentally change the audience's thinking to reach new wishes. Design emphasizes innovation, and design works need to be with thinking foundation and depth, have some meaning, and use new concepts to guide the audience's thinking, but should not work for form. A school's philosophy guides its teaching pattern, advanced school-running philosophy is the foundation for a school to have its own features, and lifting the school-running philosophies is the fundamental for the art design education reform.

\section{Emphasize Personalities}

Teaching assimilation is always a common problem of China's design teaching. Unlike the education of other majors, design education should pay more attention to personalities, consciously form the educatees' personalities, make their personalities get developed positively, fully and freely, and train their independence, uniqueness, creativity and personality integrity. The students are required to discover the natures of things by their unique sensitivity and express them in their unique design languages. Different colleges have different resources, foundations, student sources and methods. On the premise of fully mastering information and their unique features and directions, establishing targeted and goal-oriented course forms and teaching methods is the prerequisite for success.

\section{Value Innovation}

The feature of art design education is that it considers the training of creative thinking ability as the core which runs through the entire process of design education. It is a peculiar phenomenon that China's design teaching uses one and the topic for one or two decades. Innovation is the nature of design, so is teaching, curriculum innovation is the life of teaching development. Many students don't have strong creativity, one of the important reasons is that the domestic design education adopts the same measurement pattern to manage design teaching, measure students' academic performance by only depending on the paper quality, and use a single pattern to measure all the talents. But in fact, the design-related majors aim to train students' innovative thinking and ability and try to improve the students' entire art accomplishment, and more importantly, train down-to-earth and strongly creative students, which is also the core issue in design education. Designers should value innovation, especially originality. Students are trained to express their thoughts in their own unique design languages which are different from the others', including the expressive forms and contents of their works. The major of design has a greater demand for innovation concepts than the other ones. Only when we respect the particularities of different disciplines and furthest develop students' independent creativities and imaginations, can we fundamentally raise our design education quality, and improve the situation of weak design ability and market adaptability.

\section{Summary}

To sum up, China's design and design education are in a critical development stage, and China's current art design education should remain its distinct national features and independence while absorbing the western education advantages. Though colleges have different features due to 
different regions or discipline setup, their common education features should be that they provide students with heuristic learning environments, the teachers should center on student demands in teaching activities, focus on stimulating their creativity, exercise their multi-consciousness of thinking expression, train their multiple means of solving problems, and then cultivate them as the first-class art design talents for the social development.

\section{Acknowledgements}

Humanities and social Sciences research Project of QUST. Item identification number: 15XB04

\section{References}

[1] Creative China - Reconsideration about Design Education (B) Proceedings in 2006 National Art Design Education Forum, Edited by Chen Hanmin, Shanghai Book and Painting Press, Sept 2006

[2] Savannah College of Art and Design, Edited by Lan Qing, Qiu Hongzhou, China Architecture $\&$ Building Press, Oct 2005

[3] Cranbrook Academy of Art, Edited by Lan Qing, Qiu Hongzhou, China Architecture \& Building Press, Oct 2005

[4] Pin up Your Works - Study Design in America, by Liu Lanlan, China Architecture \& Building Press, April 2005

[5] Ernst H. Gombrich(British)((The Story OfArt)1985 page 4

[6] Barvier(French)((Histoire du live)2005 Guangxi Normal University Press AU rights reserved page 29

[7] Brand(British) A History of illustration 1958 London page 67

[8] Atlick(America)((The English Common Reader)1957 Chicago page 180

[9] B. Bosanquet(British) A History Of Aesthetic 2001 page 168

[10] the history of Chinese modern art design , by Rui-lin Chen changsha, hunan science and technology press, 2002 